\title{
The source of the problem
}

\author{
When Rivers Run Dry: Water - The \\ Defining Crisis of the Twenty-First Century \\ by Fred Pearce \\ Eden Books/Beacon Press: 2006. 368 pp. \\ $£ 18.99 / \$ 26.95$
}

\section{Ganesh Pangare}

A global water shortage is set to be the major crisis of the twenty-first century, so of course a vast amount has been written about it, both in the popular media and in academic books and journals. What is unique about When Rivers Run Dryby journalist Fred Pearce is the style and presentation of the facts and events that explain the causes and scale of the problem. Pearce's anecdotal style and the personal accounts of the people he met during his travels make it highly readable.

Pearce takes the reader on a journey around the world exploring the worst water-related disasters, They have occurred not only in the developing world, but also in countries that on the face of it seem to have their water problems under control. How many of us are aware that the once mighty Rio Grande has been reduced to a trickle near the US-Mexican border? Or that Libya's network of pipes known as the Great Manmade River can carry $6,500,000 \mathrm{~m}^{3}$ of water every year across 600 miles of desert? Or that Saudi Arabia grew all its wheat, and now grows its alfalfa, using very old, irreplaceable 'fossil water' from ancient aquifers? Or that the groundwater used by China, India and Pakistan is estimated to be more than half of the total used by the whole world? Or that in California, $15 \%$ more water is being pumped out than is being replenished?

If the author's intention is to shock the reader with these facts, he succeeds. However, the book tends to look more at the problems and less at the proposed solutions. Also, some of the stories - such as that of the Indian farmer who uses groundwater to grow alfalfa to feed his cattle and is part of a flourishing dairy industry — need to be viewed not only in the context of the water problem, but within the context of the larger socio-economic problems in the region. Nevertheless, despite focusing solely on water, the book contains much to appreciate.

Its value lies in the way it makes such a serious subject interesting and informative both for lay readers and water professionals. It looks at the complete spectrum of the social, political and economic complexity of water, covering issues related to surface water (rivers, lakes and wetlands), groundwater exploitation and quality, conflicts related to water, transboundary waters, floods and droughts. Crucially, many of these are viewed through the eyes of local people who are directly affected by these issues.

Interspersed in the text are large amounts

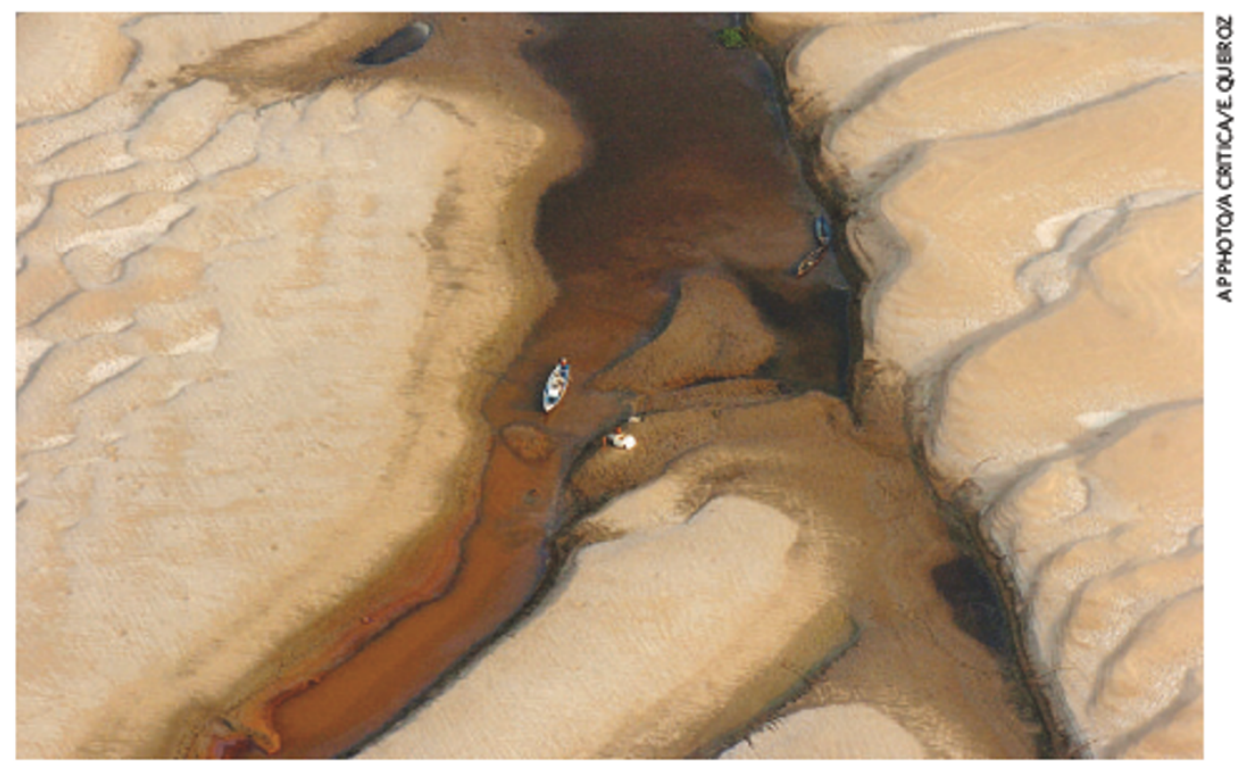

Alldried out: a boat tries to negotiate what remains of a section of the Amazon River in Brazil.

of data, but they are explained in a way that makes them easy to grasp. For example, figures for water consumption and use are defined in the context of our daily routine and activities, such as the amount of water required to grow various foods, where this water comes from, and whose water we are taking when we consume these foods. Comparisons between the way countries use and consume water are made in a similar manner. These facts are also used to explain the politics and economics of 'blue' water (found on the surface) and 'green' water (stored as soil moisture and hence available to plants), as well as the import and export of virtual water, concepts that previously remained in the domain of water professionals and academics.

Rivers are sacred to religions, symbols of nationhood, and givers of life. We need water to survive, today and in the future. The desire to meet today's needs has always influenced the way we deal with water and forced us to overcome our desire to save some for future use. But this must change or there will soon be almost none left for tomorrow, and this is the book's central message. We need to save our rivers. We need to find ways of "storing water without wrecking the environment, of restoring water to rivers, and refilling lakes and wetlands", and of sharing waters rather than fighting over them. "It requires us to go with the flow. And to do so before the rivers finally run dry."

Ganesh Pangare is director of the World Water Institute, 6 Pentium Classic Apartments, NDA-Pashan Road, Bavdhan, Pune 411021, India.

\section{A martian mystery}

\section{The Rock from Mars: A Detective Story on Two Planets \\ by Kathy Sawyer \\ Random House: 2006. 416 pp. $\$ 25.95$}

\section{John F. Kerridge}

Discovering life beyond Earth will change forever our view of the Universe and our place within it. So when a team led by David McKay of NASA's Johnson Space Center announced in August 1996 that they had found evidence for ancient life in a martian meteorite (D. S. McKay et al. Science 273, 924-930; 1996), the world sat up and took notice. How that announcement came to pass and what happened afterwards form the subject matter of The Rock From Mars.
Kathy Sawyer, a journalist formerly with The Washington Post, has produced a model of science writing for the general public. She gets the science right (with an occasional bobble), she reports with commendable balance on the intense controversy generated by McKay and colleagues' announcement, and her lucid writing should prove largely comprehensible to non-scientists. She accurately depicts the day-to-day life of the scientists involved and brings out how their observations and ideas are processed by the scientific community as it gropes its way towards the truth.

McKay's team got one thing dead right: if you want the scientific community to believe you've found evidence for extraterrestrial life, 